able persons will consider the progress of mankind, not by the years of generations merely, but by centuries or millenia. We may learn by the history of mankind in the last 20,000 years how near it has come to extinction; and we must recognize that it will take only a little interference with natural instincts and a little interference with natural selection during a few generations to bring the species, or one race of it, rather abruptly to an end, just as other human races have come to an end in historical times. The human species must eventually go the way of all species of which we have a paleontological record; already there are clear signs of a wide-spread deterioration in this most complex and unstable of all animal types. A failure to be influenced by the findings of the students of eugenics or a continuance in our present fatuous belief in the potency of money to cure racial evils will hasten the end. But if there be a serious support of research in eugenics and a willingness to be guided by clearly established facts in this field, the end of our species may long be postponed and the race may be brought to higher levels of racial health, happiness and effectiveness.

Charles B. Davenport

\section{JOEL ASAPH ALLEN}

Throvgh the death, on August 29, 1921, of Dr. Joel Asaph Allen, science has lost a pioneer and a most devoted servant. A memorable career, filled with achievement and marked by years of unflagging application and energy, has been closed in its eightyfourth year.

Joel Asaph Allen was born in Springfield, Massachusetts, July 19, 1838, of New England parentage. Through his father, Joel Allen, he traced his descent back to an Allen who came to the Colonies about 1630, while the maternal line of descent was from John Trumbull who settled in Massachusetts in 1639. The eldest of five children, his early life was spent on the paternal farm in an atmosphere of puritanical strictness. His schooling began with attendance at the rural school, generally in the winter only, because of the demands of the farm for the summer months. The boy very early displayed an intense love of nature and a keen interest in all its manifestations. While this did not meet with the wishes of his father there was no active or unkind opposition, and from his mother he met only sympathy.

Dependent at first solely upon his own efforts, without the aid of books or the acquaintance of naturalists, the boy showed a great determination to interpret the life about him. Later, when his attendance at Wilbraham Academy led up to Cambridge and the opportunity of studying under Louis Agassiz, he was prepared to make the most of every opportunity. However, this zeal for the constant study of nature, in addition to the work necessary in helping on the farm, resulted in the overtaxing of his strength and the impairment of his health, a condition which gave him much trouble throughout his lifetime and finally put an end to all field work.

His association with Agassiz began when he entered Cambridge as a special student and lasted until the latter's death. Among his associates in these classes conducted by the great teacher, were men destined to become famous, authorities in their special fields. The names of Alpheus Hyatt, E. S. Morse, A. S. Packard and A. E. Verrill are to be found on the rosters of those days at Cambridge.

The story of his schooling at Wilbraham Academy and later at Cambridge is that of a young man anxious for knowledge, but especially eager for the subjects bearing upon the natural sciences. With an ardent desire to do editorial work, young Allen found difficulty in composition and set himself to acquire this facility by keeping a daily journal, among other items making note of current weather conditions. When a summary of these weather reports were handed in as a composition at the academy, the boy was delighted to discover that Professor Marcy, his instructor, thought them worth publication. The summary came out in the New England Farmer and was the first of a long series from 
the young naturalist, then about eighteen or nineteen years of age. Thus was begun the literary career that has produced such bountiful results and the youth who forced himself to acquire. facility in a daily journal developed into the editor of not one, but several, of the foremost publications of natural science.

At the Lawrence Scientific School, at Cambridge, Allen was the pupil of men whose names stood high-Louis Agassiz, Asa Gray, Lovering and Wyman. At this school his curriculum was heavily inclined toward the natural sciences and he learned the value of accurate and painstaking observation. $\mathrm{Be}$ cause of poor health and weak eyes, the student was compelled to take instruction irregularly and to suffer many obstacles in his struggle for education.

In 1865, Agassiz invited Allen to accompany him on a collecting trip to Brazil. The party numbered sixteen and all during the voyage south Professor Agassiz gave a series of lectures to the members of his party. They landed at Rio de Janeiro and different trips were planned. Allen was assigned to a party which was to visit the northern provinces. They set out on June 9, and after delays and difficulties with their native assistants reached Lagoa Santa on July 13. This is the locality made famous by the researches of Lund and the scientists explored the caves of the region for several days. The route necessitated long hard travel, partly by river, partly by pack train. Allen's health had broken down by the end of the third month of this trying life, and he was forced to leave the others and strike out for Bahia, which he reached by the end of November, after an overland journey of nearly 600 miles. His voyage northward was not soon to be forgotten, because his ship which ran into gales off Cape Hatteras, was driven off her course and only narrowly escaped foundering. Approaching the Cape a second time, she was again met with storms and eventually reached Boston ninety days out from Bahia.

In the attempt to build up his constitution, Allen severed connections with the $\mathrm{Mu}$ - seum of Comparative Zoology and returned to the farm, but, with the partial return of strength, found the call of nature to be irresistible and made a collecting trip into the Middle West, 1867. This trip was successful in every way and when a summer had been spent out of doors and Allen felt equal to museum work once more, he wrote to Agassiz, who welcomed him back. The next eighteen years were spent at Cambridge, where he was in charge of the department of mammals and birds.

The winter of 1868-1869 was spent in East Florida where valuable material and experience was gained. Nine months were spent on a collecting trip to the Great Plains and the Rocky Mountains, in 1871-1872. Work was begun at Leavenworth. At this time there was trouble with the Indians and the small party had to exercise caution in their movements. Near Fort Hays they went on a buffalo hunt, and Allen had his first extensive experience with the mammal which was to be one of his favorites and the subject of a large monograph. Their itinerary took them through Denver and South Park, Cheyenne, Green River and Fort Fred Steele. The results of the expedition were most satisfactory and a large number of specimens were secured.

The next year, 1873, Allen made his last important field trip. He accompanied a party of railroad surveyors who were to locate the Northern Pacific Railroad westward from Bismark. It was during a period of Indian troubles, and a large military escort under General Custer went with the party. This was a historic trip, marked by skirmishes with the Indians, and by many other novel experiences. While opportunities for collecting specimens were not of the best, much of the territory traversed was zoologically unknown and much valuable information was brought back.

From 1876 to 1882 , Dr. Allen served as a special collaborator of the United States Geological Survey, devoting most of his time to original research, publishing among other papers, "The American Bisons, Living and Extinct," and monographs of various families 
of the North American Rodentia, the latter in cooperation with Dr. Elliot Coues. At this time his interest was drawn to marine mammals and after he published a "History of North American Pinnipeds" he took up the Cetaceans, but illness checked the work before it was finished and the results never were printed. A short trip to Colorado was taken, upon the advice of a physician, in the attempt to throw off this illness, but a nervous breakdown resulted and it was months before active work could be resumed.

In 1885, the financial resources of the $\mathrm{Mu}$ seum of Comparative Zoology were so restricted as to cut down opportunities for the staff, and Dr. Allen accepted a curatorship in the American Museum of Natural History in New York City. He took over his duties on May 1, 1885, and served thirty-six years in that capacity, as curator of the department of ornithology and mammalogy. Later this department was divided into the department of mammalogy and the department of ornithology, Dr. Allen retaining the curatorship of the former department. In 1921, he was made honorary curator in order to give him entire freedom for research work.

At the time he took over the department, the collections were very small with no research facilities, and no study collection to serve as the basis for original work. During his tenure, the department entered upon a period of growth and expansion of marvelous proportions. At first he was alone, without any assistants, but in 1888, he was given his first assistant, Mr. Frank M. Chapman, and later others joined the department until at the time of his death, the scientific staff of the two departments which were formerly his department, numbered ten, besides non-staff assistants and field collectors. Collections were brought in, first from the United States, Mexico and British Columbia; and then the scope of activities was enlarged to take in South America, Africa and the Orient. In 1921, his department had parties in the field and plans for work in Asia, Africa, Australia, North America, South America and the West Indies.
Coincident with the vast accumulation of research collections, which grew from practically nil, in 1885 when the new curatior took charge, to a total of about 50,000 specimens of mammals in 1921, there has been a corresponding increase in the number of mammal groups placed upon exhibition in his department. There has been a transition from the hall filled with a heterogeneous assemblage of mounted individuals to halls given over to carefully planned habitat groups which tell a story. Publications from the department of mammals may be said to begin with Dr. Allen's curatorship and the total number of scientific papers written by him in this capacity is a surprisingly large number.

While Dr. Allen devoted his later years almost exclusively to research in mammalogy, the sum total of his endeavors discloses work in many other branches of natural science. The bibliography, published, in the volume also containing the autobiography ${ }^{1}$, contains the following large numbers of titles: papers on mammals, 271 ; on birds, 966 ; on reptiles, 5 ; on zoogeography, 9 ; on evolution, 22 ; in nomenclature, 35 ; on biography, 134; miscellaneous, 20 ; a grand total of 1,433 titles published up to 1916. Since 1916 many other papers have appeared and a great deal of manuscript has been prepared which has not been published. When it is considered that each one of these publications is a well thought out piece of work, in most cases necessitating days spent in the study of material, and that many of them are papers of length, such as his monographs on the bison, the seals or the musk ox, which contain several hundred pages of text, then one is forced to marvel at the amount of mental labor involved and the tireless energy that drove the man.

His youthful yearnings for editorial work were realized to the full. Beginning with the year 1874, when he edited a volume of the Proceedings of the Boston Society of Natural

1 " Autobiographical Notes and a Bibliography of the Scientific Publications of Joel Asaph Allen." American Museum of Natural History in 1916. 
History, he served continuously as the editor of one or more scientific publications until 1918, when he was forced to give up editorial work because his advancing age demanded that he restrict his activities. For forty-four years he acted in editorial capacities and some of these publications ranked with the foremost in natural science. From 18841911, he was editor of the $A u k, A$ Quarterly Journal of Ornithology, the publication of the American Ornithologists Union, during which time twenty-eight volumes appeared. As a testimonial to the esteem in which his tenure was held by his fellow ornithologists, Witmer Stone, the succeeding editor of The Auk, wrote:

Beginning with the initial volume of the Bulletin of the Nuttall Ornithological Club, and continuing to the present year, Dr. Allen has, without intermission, guided the course of this journal and its successor The Auk; and the series of thirty-six volumes stands as a perpetual monument to his ability, and his painstaking devotion to the cause of ornithology and the interests of the American Ornithologists' Union. There have been few continuous editorships of equal length in the history of scientific periodicals.

An even longer editorial service was rendered to the Bulletin of the American $\mathrm{Mu}$ seum of Natural History, for beginning with the first volume, 1886, he directed the ever lengthening series until 1918, a total of thirty-two years. From the standpoint merely of routine accomplishment, this would stand as an editorial achievement to be envied, but with Dr. Allen, editorial duty meant more than that and each contribution was read as painstakingly and given the same attention as he gave to his own personal contributions.

Nor was he content to rest his editorial laurels upon these two terms of service but edited the zoological numbers of the Memoirs of the American Museum of Natural History from 1893 to 1918, and was the editor, or a joint editor, of the two editions of the "Check-Iist of North American Birds," 1895 and 1910, "Supplement to the Code of Nomenclature and Check-List of North American Birds," 1889, and "The Code of Nomenclature" adopted in the American Ornithologists Union, 1908.

Among his first papers are many of a philosophical nature, such as articles on the geographical variation in mammals and birds, the geographical distribution of mammals and the laws that govern the distribution of animal life, the genesis of species, the instinct of migration, etc. It is quite likely that his inclination in this direction would have led to many other papers along similar lines, but when material from the field began to come into his department at the American $\mathrm{Mu}$ seum, it became necessary for him to devote his entire time to the building up of the department and the identification of species.

His philosophical papers show the result of close observation and keen analysis and some of his deductions are recognized today as natural laws. In 1876, in his "Geographical Variation among North American Mammals" he set forth the following:

In a general way, the correlation of size with geographical distribution may be formulated in the following propositions:

1. The maximum physical development of the individual is attained where the conditions of environment are most favorable to the life of the species. Species being primarily limited in their distribution by climatic conditions, their representatives living at or near either of their respective latitudinal boundaries are more or less unfavorably affected by the influences that finally limit the range of the species. . . .

2. The largest species of a group (genus, subfamily, or family, as the case may be) are found where the group to which they severally belong reaches its highest development, or where it has what may be termed its center of distribution. In other words, species of a given group attain their maximum size where the conditions of existence for the group in question are the most favorable, just as the largest representatives of a species are found where the conditions are most favorable for the existence of the species.

3. The most " typical" or most generalized representatives of a group are found also near its center of distribution, outlying forms being generally more or less " aberrant" or specialized. Thus the Cervide, though nearly cosmopolitan in their distribution, attain their greatest development, both 
as respects the size, and the number of species, in the temperate portions of the northern hemisphere. The tropical species of this group are the smallest of its representatives. Those of the temperate and cold temperate regions are the largest, where, too, the species are the most numerous. . . . The possession of large, branching, deciduous antlers forms one of the marked features of the family. These appendages attain their greatest development in the northern species, the tropical forms having been reduced almost to mere spikes, which in some species never pass beyond a rudimentary state. . . .

A paper published in 1871 " On the Mammals and Winter Birds of East Florida, with an Examination of certain assumed Specific Characters in Birds" brought forth the following comment from Coues:

The article gained the Humboldt Scholarship, and is one of the most important of American ornithological works.

His work in taxonomy covered almost the entire mammal fauna of the world, from marsupials to monkeys, from shrews to whales, while his field of research has been at times in every one of the continental areas. The greater number of his papers are systematic taxonomic reports and the descriptions of new forms. He is the author of nearly seven hundred new mammal names, and fifty-three bird names.

Some of the most important of the accomplishments of Dr. Allen have been his labors in the field of scientific nomenclature, a field where authoritative workers are scarce because of the exacting demands of the problems. His knowledge of scientific literature was so deep, his memory for authors and dates so unusual, that he took particular delight in the solution of the weightest nomenclatural problems. His opinions command respect from scientists the world over and this fact has long been recognized in the positions held by the doctor on committees on nomenclature of both national and international organizations. It is in this field that the loss of his contributions will be most keenly felt.

He was a member of the Commission on Nomenclature of the International Congress of Zoology since 1910 and attended the meeting in Monaco in 1913.

A man of extreme modesty and retiring temperament, indeed bashful, he strove for no titles, sought for no publicity. Honors, however, came to him unasked. In 1886 he was granted the degree of Ph.D. by Indiana University; in 1903, he was awarded the Walker Grand Prize, Boston Society of Natural History, and in 1916 the Medal of the Linnæan Society of New York. He was a fellow or member of no less than thirty-three scientific societies in the United States and abroad.

$\mathrm{He}$ held high positions in many scientific organizations, the more important being that of president of the American Ornithologists Union, 1883-1891; an incorporator of the (first) Audubon Society for the Protection of Birds, 1886; a Founder and Director of the Audubon Society of the State of New York, 1897-1912; Vice-president of the New York Academy of Sciences, 1891-1894; President of the Linnæan Society of New York, 1890-1897; etc.

Dr. Allen possessed to a rare degree the faculty of concentration and devotion to his work. Not content with the amount of work done at his office in the museum, he carried books and material home with him, and his ideal vacation was one where he might take some special subject away with him where he could study unmolested. In brief, he lived for his work and to the psychology of this devotion may possibly, in part, be attributed his ripe age, attained in spite of long periods of ill health.

No one associated with Dr. Allen could fail to be impressed, not only with the very evident scholarly attainments of the man, but with his sincerity and simplicity. From a profound respect for his work, one passed readily to a love for the man, and an association with him in any work could be counted, not only as a most valuable mental training, to be prized in later years, but as a friendly contact no less to be remembered.

Dr. Allen married, in 1874, Mary Manning Cleveland and a son, Cleveland Allen was born to them. His wife died in 1879 and for seven years the doctor remained single. In 1886 he 
married Susan Augusta Taft, who with his son Cleveland survives him. Dr. Allen's home life was idyllic and to this inspiration he was wont to attribute the achievements of his later life and the activity of his older years.

With the passing of Dr. Joel Asaph Allen the world has lost an earnest and sincere student, natural science has lost the power of an able pen backed by the searching analysis of level judgment, while his personal friends will mourn the loss of all this and more, for they have known him as a man.

American Museum of Natural History

\section{SCIENTIFIC EVENTS}

\section{THE DANISH DEEP-SEA EXPEDITION}

We find in Nature an account of the Danish Deep-Sea Expedition, which left Copenhagen on August 30 on board the new research steamer Dana. It plans to spend about ten months in the temperate and tropical parts of the North Atlantic. The object of the expedition is to carry out deep-sea investigations in accordance with a scheme which was submitted by the leader of the expedition, Dr. Johs. Schmidt, to the International Council for the Exploration of the Sea during their meeting at Copenhagen in July last.

The Dana, of the Lord Mersey trawler type, was bought in England by the Danish Government to replace the old research steamer Thor, which was sold some years ago. The Dana has been equipped for marine research work at the Royal Dockyard, Copenhagen. She has a length of about $140 \mathrm{ft}$. between perpendiculars, and is 325 tons gross register. She carries a 600 -h.p. triple expansion engine, giving her a speed of 9 knots. A large deckhouse has been constructed, which contains two laboratories-a larger biological laboratory with accommodation for five workers, and a smaller one for hydrographical work with room for two-together with a messroom for the scientific staff, and a cabin for the leader of the expedition. Below deck are the cabins of the scientific staff, and storerooms for the various instruments, fishing gears, collections, ete. The winches are worked by steam. A big trawl-winch placed forward has two drums, the smaller carrying 4000 meters of steel wire $14 \mathrm{~mm}$. in diameter for trawling at moderate depths, and the larger, carrying 10,000 meters of steel wire tapering from $14 \mathrm{~mm}$. to $7 \mathrm{~mm}$. in diameter, to be used for greater depths. The three winches for vertical hauls (water-bottles, plankton nets, and sounding) are placed on the port side of the ship; one works the lucas sounding machine and a drum carrying 6,000 meters of phosophor-bronze wire; another is a small hand-winch to be used for the surface layers; and the third works a big drum carry. ing 10,000 meters of steel wire $4 \mathrm{~mm}$. in diameter. The steel-wire ropes have been supplied by Messrs. Craven and Speeding Bros., Sunderland, and the hydrographical instruments by the Laboratoire Hydrographique, Copenhagen, of which Professor Martin Knudsen is director.

The personnel of the expedition is as follows:-Dr. Johs. Schmidt, leader of the expedition; Dr. J. N. Nielsen (Meteorological Institute, Copenhagen), hydrographer; $\mathrm{P}$. Jespersen and A. V. Taaning (Danish Committee for the Study of the Sea); K. Stephensen (Zoological Museum, Copenhagen); J. Olsen (Polytechnic College, Copenhagen), assistant hydrographer. N. C. Anderson, ship's doctor, will also take part in the investigations. Professor C. H. Ostenfeld expects to join the expedition later on during its stay in West Indian waters.

\section{THE FIFTH AVENUE HOSPITAL OF NEW YORK}

The Fifth Avenue Hospital Association is making an urgent plea for contributions to complete the construction of the new building at 105th Street and Fifth Avenue. The institution will combine the present Hahnemann Hospital and the Laura Franklin Free Hospital for Children. Dr. Wiley E. Woodbury, director of the hospital, has made a statement for the New York Evening Post in which he says:

There is an enormous waste in the administration of the free ward, which is not realized by any 